\title{
Excretion of purine derivatives by ruminants : effect of exogenous nucleic acid supply on purine derivative excretion by sheep
}

\author{
BY X. B. CHEN, F. D. DeB. HOVELL, E. R. ØRSKOV AND D. S. BROWN \\ Rowett Research Institute, Bucksburn, Aberdeen AB2 $9 S B$
}

(Received 29 March 1989 - Accepted 15 September 1989)

\begin{abstract}
The present study examined the relationship between the supply of exogenous nucleic acid (NA) purines and their recovery as the derivatives hypoxanthine, xanthine, uric acid and allantoin in urine. Six lambs, totally nourished by intragastric infusions of volatile fatty acids (VFA) and casein (i.e. no rumen fermentation), were given by abomasal infusion a microbial NA concentrate at six levels (from zero to $24.5 \mathrm{mmol}$ purines/d). The true digestibility between the abomasum and terminal ileum of the NA purines was measured in a separate experiment using three lambs. The relative proportion of urinary allantoin increased, and that of other derivatives decreased, as the amount of NA infused was increased. The relationship between total excretion of purine derivatives $(Y ; \mathrm{mmol} / \mathrm{d})$ and exogenous purines absorbed $(X ; \mathrm{mmol} / \mathrm{d})$ was $Y=0.84 X+0.150 \mathrm{~W}^{0.75} e^{-0.25 X}$, where $\mathrm{W}$ is body-weight $(\mathrm{kg})$. This implies that the endogenous contribution to the total excretion of derivative decreased as the supply of exogenous purines increased, with an associated progressive replacement of de novo synthesis by exogenous purines. The model also implies that 0.16 of the purines were eliminated through routes other than derivative excretion in urine. Once excretion exceeded $0.6 \mathrm{mmol} / \mathrm{kg} \mathrm{W}^{0.75}$ per $\mathrm{d}$, endogenous excretion was effectively zero and thus $Y=0.84 X$. In normally fed sheep, derivative excretion should therefore relate to the microbial purines and, hence, microbial protein absorbed according to these models. The changing proportions of allantoin and other derivatives in urine were probably due to changes in the relative importance of endogenous and exogenous purines as precursors.
\end{abstract}

Nucleic acids: Purine derivatives: Sheep

Studies on the urinary excretion of purine derivatives by ruminants have been stimulated by the possible use of their excretion as an estimator of the rumen microbial protein supplied to the host animal. This is because in ruminants nucleic acids (NA) flowing to the small intestines are essentially of rumen microbial origin (McAllan \& Smith, 1973). Absorbed purines are degraded to hypoxanthine, xanthine, uric acid and allantoin, which are excreted in urine, and should relate quantitatively to the amount of purines and, hence, microbial protein absorbed.

The excretion of allantoin has been shown to be correlated with the amount of NA infused post ruminally to sheep (Antoniewicz et al. 1980; Sibanda et al. 1982; Giesecke et al. 1984; Lindberg, 1985; Fujihara et al. 1987). However, recoveries of NA-nitrogen as allantoin- $\mathrm{N}$ reported by these authors varied from 0.12 to 0.47 (i.e. purine recoveries of $0 \cdot 22-0 \cdot 79$ ). Since uric acid, xanthine and hypoxanthine were not measured, it is not possible to assess whether the recovery of absorbed purines as the derivatives in the urine was complete in these studies. It is also not clear from the existing information whether, and to what extent, exogenous purines would be retained by the animal body.

In the studies to be reported here the intragastric infusion technique (Ørskov et al. 1979) was employed. With this technique, the microbial fermentation in the rumen is eliminated and exogenous purines supplied to the animal could be precisely controlled, enabling a close examination of the input-output relationships. Uric acid, xanthine plus hypoxanthine, 
and allantoin were measured. These four compounds are referred to in the present report as 'purine derivatives'.

\section{EXPERIMENTAL}

Three experiments were conducted. Expt 1 was designed to examine the urinary excretion of purine derivatives by sheep receiving different amounts of exogenous purines as a microbial NA concentrate infused into the abomasum. In Expt 2 the digestibility of the purines in this NA concentrate between the abomasum and terminal ileum was measured. In Expt 3 the plasma concentrations of purine derivatives in portal and jugular blood were measured.

\section{Animals and management}

Six female lambs (Blackface $\times$ Suffolk, 31-38 kg) were used in Expt 1 and three lambs (same breed, $23-32 \mathrm{~kg}$ ) in Expt 2. All animals were fitted with a permanent rumen cannula and an abomasal catheter. The three lambs used in Expt 2 were also fitted with a simple ' $T$ " cannula at the terminal ileum about $150-200 \mathrm{~mm}$ from the ileo-caecal junction. All animals were kept in metabolism cages and nourished by continuous infusion of volatile fatty acids (VFA) into the rumen and casein into the abomasum. Details of the surgical procedures and intragastric infusion method were as described by Hovell et al. (1987). Two Blackface wether sheep of about $60 \mathrm{~kg}$ were used in Expt 3. They had been fitted with a PVC catheter (2.5 mm o.d., $1.5 \mathrm{~mm}$ i.d., Dural Plastics and Engineering, Auburn, NSW, Australia) located in the portal system via a mesenteric vein.

\section{Treatments and design}

Expt 1. All animals received a constant supply of energy (from VFA) at 1.5 times maintenance requirement $\left(675 \mathrm{~kJ}\right.$ metabolizable energy $/ \mathrm{kg}$ body-weight $(\mathrm{W})^{0.75}$ per $\mathrm{d}$ ). The animals were given six levels of NA infused into the abomasum over six successive $5 \mathrm{~d}$ periods. A microbial NA concentrate (Pruteen N14; ICI Ltd, Cleveland) was used as the NA source. It contained $0.657 \mathrm{~g} \mathrm{NA} / \mathrm{g}$ dry matter (DM) and $0.814 \mathrm{mmol}$ purines/g DM $(0.381 \mathrm{mmol}$ adenine and $0.433 \mathrm{mmol}$ guanine). The six infusion levels were $0,4,8,12,16$ and $20 \mathrm{~g} \mathrm{NA} / \mathrm{d}$. These amounts correspond to the quantities of microbial NA (or purines) likely to be produced when animals are normally fed between 0 and about 1.8 times the maintenance energy requirement (Agricultural Research Council, 1984). Three lambs were given the NA in progressively increasing amounts and the other three in decreasing amounts.

Casein was supplied to the animals in a constant proportion to NA. A mixture of casein ( $1 \mathrm{~g} \mathrm{~N} / 1$ ) and Pruteen ( $1 \mathrm{~g} \mathrm{NA} / \mathrm{l}$ ) was prepared for the abomasal infusion; the NA-N accounted for 0.126 of the total $\mathrm{N}$, approximately the same proportion as found in rumen microbes (Storm \& Orskov, 1983). This was designed to simulate the situation when animals receive microbial cells as the only source of protein supply. The above mixture was diluted to 3 litres with water as the final abomasal infusate.

Expt 2. Since the remaining supply of Pruteen N14 was limited, the experimental design and replication possible were constrained. Five treatments were imposed which were randomly allocated to the three lambs over five $4 \mathrm{~d}$ periods: (1) $4 \mathrm{~g}$ casein- $\mathrm{N} / \mathrm{d}$ only, (2) $8 \mathrm{~g}$ casein- $\mathrm{N} / \mathrm{d}$ only, (3) $4 \mathrm{~g} \mathrm{NA} / \mathrm{d}$ plus $4 \mathrm{~g}$ casein- $\mathrm{N} / \mathrm{d}$, (4) $4 \mathrm{~g} \mathrm{NA} / \mathrm{d}$ plus $8 \mathrm{~g}$ casein- $\mathrm{N} / \mathrm{d}$, (5) $8 \mathrm{~g} \mathrm{NA} / \mathrm{d}$ plus $8 \mathrm{~g}$ casein- $\mathrm{N} / \mathrm{d}$.

Each day, 100 g cellulose (Avicel CL-611; Honeywill and Stein, Wallington, Surrey) were added to the Pruteen-casein mixtures to increase the solid matter flow of ileal digesta and $3 \mathrm{~g}$ chromium-mordanted cellulose (prepared using the method of Uden et al. 1980) were added as a marker. Since the final abomasal infusate was rather viscous, a small bench stirrer was used to maintain the infusate as a homogenous suspension during infusion. 
Expt 3. The animals were kept in metabolism cages and were given $2 \mathrm{~kg} / \mathrm{d}$ of a pelleted ration containing 0.50 hay, 0.30 rolled barley and 0.10 molasses as two equal meals at 08.30 and 16.00 hours.

\section{Sample collection}

In Expts 1 and 2 a daily total urine collection was made into sulphuric acid (final $\mathrm{pH}$ of urine was kept below 3 ). Urine samples were stored at $4^{\circ}$ and analysed within 1 week. In Expt 2, ileal digesta samples were collected at about $1 \mathrm{~h}$ intervals during the last $6-8 \mathrm{~h}$ of each treatment period. The samples were frozen immediately, freeze-dried and ground for the analyses of purines (adenine and guanine) and Cr. In Expt 3, blood was sampled from the portal (from the catheter) and jugular (venepuncture) veins on $4 \mathrm{~d}$ at about 15.00 hours, immediately heparinized, spun at $2200 \mathrm{~g}$ for $20 \mathrm{~min}$, and stored at $-20^{\circ}$.

\section{Analytical methods}

Measurement of urinary and plasma purine derivatives. Allantoin was measured using the AutoAnalyzer method of Pentz (1969) with some modifications. Uric acid was determined using a phosphotungstic acid method adopted on the AutoAnalyzer (Technicon Instruments Co., 1979). The content of xanthine plus hypoxanthine was measured as the increase in uric acid after treating the urine sample with xanthine oxidase. Details are given by Chen (1989).

Measurement of total purine content in Pruteen and ileal digesta samples. The samples $\left(0.2 \mathrm{~g}\right.$ Pruteen or $0.5 \mathrm{~g}$ ileal digesta) were treated with $1 \mathrm{M}$-hydrochloric acid at $100^{\circ}$ for $1 \mathrm{~h}$ and subsequently with $0.2 \mathrm{M}$-perchloric acid at room temperature for $30 \mathrm{~min}$ to liberate the bound purine bases. The solution was neutralized by addition of $3 \mathrm{M}$-potassium hydroxide to $\mathrm{pH} 7$ and the precipitated potassium perchloride removed by centrifugation. The supernatant fractions were kept at $-20^{\circ}$ until analysis of adenine and guanine contents by high-performance liquid chromatography (HPLC). Caffeine was used as an internal standard and added to each sample before the acid hydrolysis. Details of this procedure are described by Chen (1989). The HPLC system used consisted of the Pye Unicam PU-series pumps, uv detector (set at $260 \mathrm{~nm}$ ) and computing integrator. A $250 \mathrm{~mm} \times 4.6 \mathrm{~mm} \mathrm{C}-18$ reverse-phase column (Spherisorb 1) was used. Solvent A was $0.01 \mathrm{M}$-ammonium dihydrogen phosphate $(\mathrm{pH} 7.0)$ and solvent $\mathrm{B}$ a mixture of 0.80 solvent $\mathrm{A}$ and 0.20 methanol. Flow rates at different times were $1.0(0-15 \mathrm{~min}), 2.5(15-32 \mathrm{~min})$ and $1.0(32$ $40 \mathrm{~min}) \mathrm{ml} / \mathrm{min}$. The gradient for solvent $B$ was $0(0-5 \mathrm{~min}), 0 \cdot 30(5-10 \mathrm{~min}), 1 \cdot 00(15-30 \mathrm{~min})$ and $0(32-40 \mathrm{~min}) . \mathrm{Cr}$ in the ileal samples was determined by the method of Stevenson \& deLangen (1960).

\section{Statistical methods}

Analysis of variance and simple linear regression was performed using 'Genstat 4' (Lawes Agricultural Trust, 1983). The effect (linear and quadratic) of NA infusion on the urinary purine derivative excretion, and the differences between days and between the two groups of animals given an increasing or a decreasing NA input, were examined. The maximum likelihood program (Ross, 1987) was employed for the curve fitting and parallel curve analysis.

\section{RESULTS}

Expt 1. Adenine and guanine were not found in the urine samples and, therefore, the sum of allantoin, uric acid and xanthine plus hypoxanthine should comprise all the purine compounds excreted in the urine. The excretion of total purine derivatives responded rapidly to changes in level of NA infusion (Table 1). This rapidity of response was examined by comparing the five daily measurements within each period of infusion. At 
Table 1. Expt 1. Excretion (mmol/d) of total purine derivatives (allantoin, uric acid and xanthine plus hypoxanthine) by lambs receiving an abomasal infusion of a microbial nucleic acid (NA) concentrate (Pruteen N14)*

(Each value is the mean of three lambs)

\begin{tabular}{|c|c|c|c|c|c|c|c|c|}
\hline \multicolumn{2}{|c|}{ Levels of infusion } & \multicolumn{5}{|c|}{ Day of infusion } & \multirow[b]{2}{*}{ Mean $\dagger$} & \multirow[b]{2}{*}{$F$ test $\ddagger$} \\
\hline $\mathrm{NA}(\mathrm{g} / \mathrm{d})$ & Purines $(\mathrm{mmol} / \mathrm{d})$ & 1 & 2 & 3 & 4 & 5 & & \\
\hline \multicolumn{9}{|c|}{ (a) Nucleic acid infusion progressively increased } \\
\hline 0 & 0 & $2 \cdot 41$ & $2 \cdot 15$ & 1.90 & 1.72 & 1.61 & 1.85 & NS \\
\hline $4 \cdot 0$ & 4.91 & $3 \cdot 56$ & $4 \cdot 06$ & $4 \cdot 40$ & $4 \cdot 25$ & $4 \cdot 10$ & $4 \cdot 20$ & NS \\
\hline $8 \cdot 0$ & $9 \cdot 82$ & $6 \cdot 47$ & 6.75 & $6 \cdot 32$ & $7 \cdot 56$ & 7.85 & $7 \cdot 12$ & NS \\
\hline $12 \cdot 0$ & 14.73 & $10 \cdot 71$ & $10 \cdot 72$ & 10.21 & $10 \cdot 59$ & $10 \cdot 51$ & $10 \cdot 51$ & NS \\
\hline $16 \cdot 0$ & 19.63 & 12.99 & $15 \cdot 14$ & $14 \cdot 47$ & $15 \cdot 24$ & 15.92 & $15 \cdot 19$ & $P<0.05$ \\
\hline $20 \cdot 0$ & $24 \cdot 63$ & $18 \cdot 18$ & $19 \cdot 80$ & $19 \cdot 57$ & $18 \cdot 92$ & $20 \cdot 15$ & $19 \cdot 61$ & $P<0.05$ \\
\hline \multicolumn{9}{|c|}{ (b) Nucleic acid infusion progressively decreased } \\
\hline $20 \cdot 0$ & $24 \cdot 63$ & $14 \cdot 66$ & $18 \cdot 36$ & 17.99 & $19 \cdot 22$ & 18.72 & 18.57 & $P<0.001$ \\
\hline $16 \cdot 0$ & 19.63 & $16 \cdot 36$ & 13.95 & $14 \cdot 53$ & 13.59 & 15.03 & $14 \cdot 28$ & $P<0.01$ \\
\hline $12 \cdot 0$ & 14.73 & 11.91 & 11.48 & 11.75 & $11 \cdot 27$ & $11 \cdot 17$ & 11.42 & NS \\
\hline 8.0 & 9.82 & 9.92 & 8.28 & 7.93 & 7.84 & 8.17 & 8.06 & $P<0.05$ \\
\hline $4 \cdot 0$ & 4.91 & 5.52 & 5.06 & 4.99 & 4.59 & $5 \cdot 15$ & 4.95 & NS \\
\hline 0 & 0 & $3 \cdot 19$ & $2 \cdot 13$ & $2 \cdot 09$ & $2 \cdot 36$ & $2 \cdot 43$ & 2.25 & NS \\
\hline
\end{tabular}

NS, not significant.

* For details, see p. 132.

+ Mean of days 2-5.

$\ddagger$ Difference between the first day and the mean of the last $4 \mathrm{~d}$; SED (a) $0.589,(b) 0.603$.

higher levels of purine infusion, the excretion for day 1 differed significantly from those of the last $4 \mathrm{~d}$ of the same period, at lower levels this was not significant statistically, but there was still the suggestion of a small carry-over effect from the preceding period. When the means of days 2-5 were considered, there were no significant differences between individual lambs nor between the two groups of animals given progressively increasing or decreasing exogenous purine inputs (Table 1). The means of the last $4 \mathrm{~d}$ measurements have been used to represent the urinary excretion for the relevant level of purine infusion (Table 2).

Daily excretion of total purine derivatives $(Y ; \mathrm{mmol} / \mathrm{d})$ was correlated with the quantity of purines infused $(X ; \mathrm{mmol} / \mathrm{d}$ ), with a linear component being: $Y=1.32$ (SE 0.46) +0.695 (SE 0.031) $X(r 0.99, P<0.001)$. There was, however, also a quadratic component $(P<$ $0.001)$ in the above correlation. The fitted intercept in the linear equation was lower than the measured endogenous excretion, which was 2.06 (SE $0 \cdot 18$ ) $\mathrm{mmol} / \mathrm{d}$ or 150 (SE 15) $\mu \mathrm{mol} / \mathrm{kg} \mathrm{W}^{0.75}$ per $\mathrm{d}$ for the six sheep. When corrected with the assumption of a constant contribution of endogenous excretion, urinary recovery of infused purines as their derivatives ranged from 0.51 to $0.69(\mathrm{mmol} / \mathrm{mmol})$ and increased with the level of infusion (Table 2). This observation was consistent with all animals.

A further feature of the purine derivative excretion was that the excretion of the different derivatives did not change uniformly with the level of purine infusion. The majority of the increased excretion associated with increases in exogenous (infused) NA was as allantoin (Table 2). Allantoin excretion increased from 0.56 to 0.81 of total derivative excretion, whereas the proportions of xanthine plus hypoxanthine and of uric acid decreased from 0.17 to $0 \cdot 06$, and $0 \cdot 27$ to 0.13 respectively (Fig. 1 ).

Expt 2. The apparent digestibility of purines averaged 0.890 (SE 0.021 ). When corrected for the endogenous purines in the ileal digesta at zero infusion of NA, the 'true' digestibility 


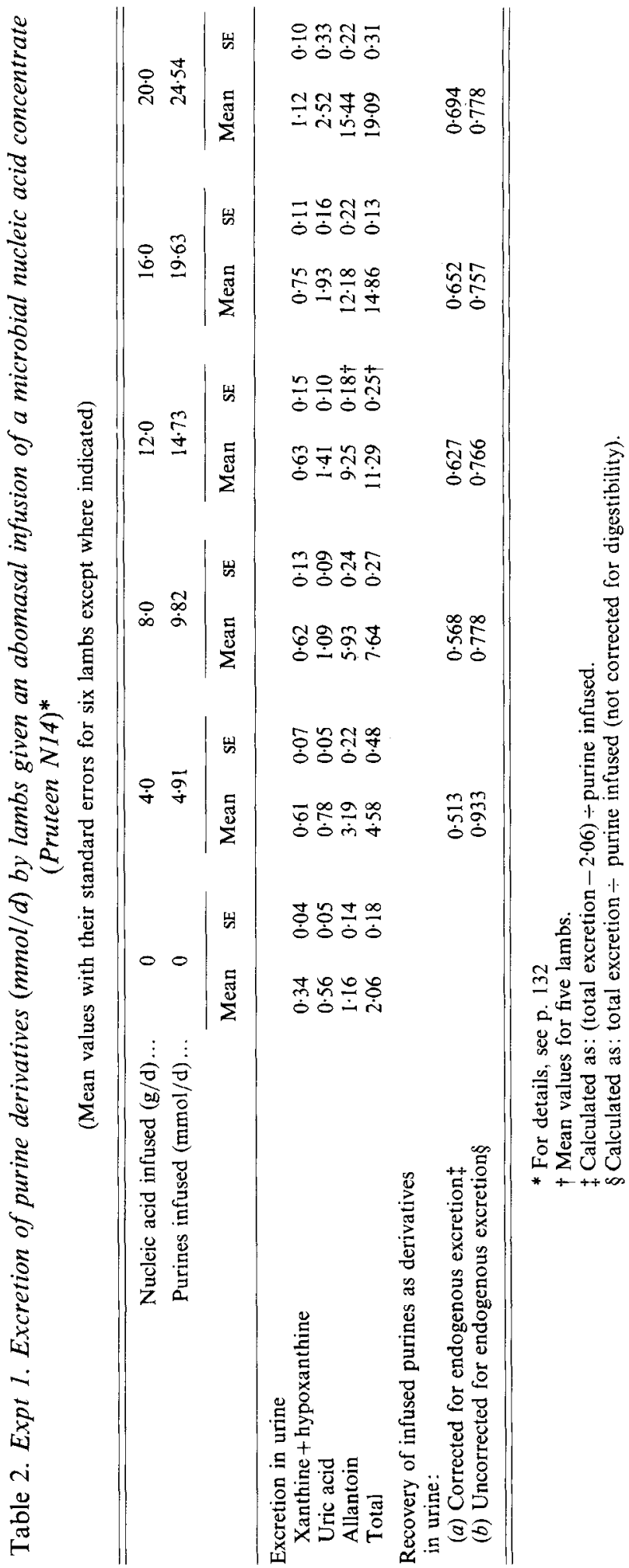




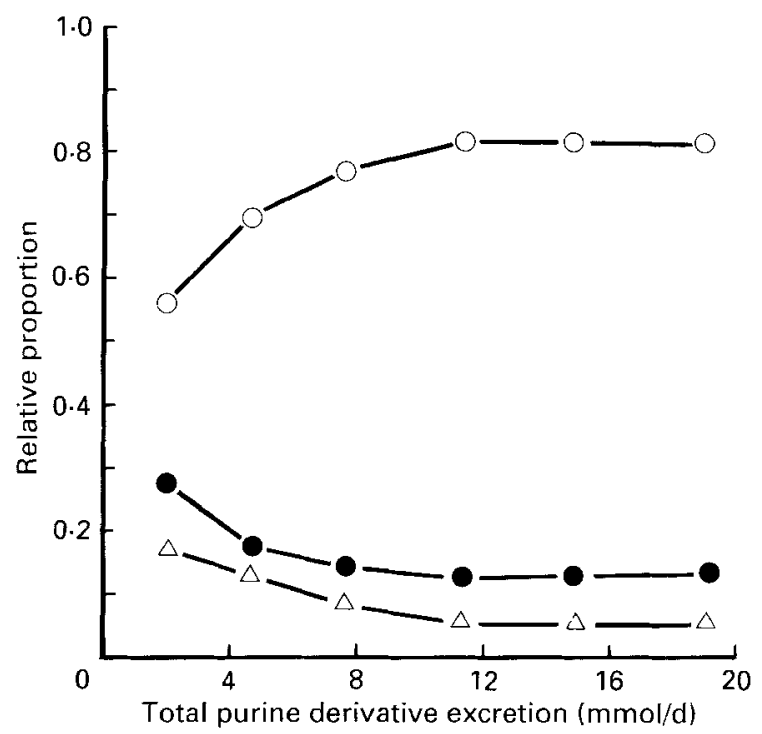

Fig. 1. Expt 1. The relative proportions of the allantoin $(\bigcirc)$, uric acid $(O)$ and xanthine plus hypoxanthine $(\triangle)$ excreted in urine of six lambs given an abomasal infusion of a microbial nucleic acid concentrate Pruteen N14 (for details, see p. 132). Points are means with their standard errors being completely masked by the symbols.

Table 3. Expt 2. Recovery as urinary purine derivatives of the digestible purines in lambs given an abomasal infusion of a microbial nucleic acid $(N A)$ concentrate (Pruteen N14)*

(Means of three lambs)

\begin{tabular}{|c|c|c|c|c|c|}
\hline Treatment no.... & 1 & 2 & 3 & 4 & 5 \\
\hline NA infused $(\mathrm{g} / \mathrm{d}) \ldots$ & 0 & 0 & $4 \cdot 0$ & $4 \cdot 0$ & $8 \cdot 0$ \\
\hline Casein-nitrogen-infused $(\mathrm{g} / \mathrm{d}) \ldots$ & $4 \cdot 0$ & $8 \cdot 0$ & $4 \cdot 0$ & $8 \cdot 0$ & $8 \cdot 0$ \\
\hline \multicolumn{6}{|l|}{ Purines (mmol/d) } \\
\hline Infused & 0 & 0 & 4.90 & 4.90 & $9 \cdot 80$ \\
\hline \multicolumn{6}{|l|}{ In ileal digesta $\dagger$} \\
\hline Mean & $0-12$ & $0 \cdot 20$ & $0 \cdot 58$ & $0 \cdot 70$ & 0.69 \\
\hline $\mathrm{SE}$ & $0-02$ & 0.05 & 0.05 & $0 \cdot 23$ & $0 \cdot 13$ \\
\hline Truly digested $\ddagger$ & & & $4 \cdot 48$ & $4 \cdot 36$ & $9 \cdot 27$ \\
\hline \multicolumn{6}{|l|}{ Purine derivative excretion (mmol/d) } \\
\hline Mean & $2 \cdot 90^{\mathrm{d}}$ & $3.21^{\mathrm{c}}$ & $5.01^{\mathrm{b}}$ & $4 \cdot 80^{b}$ & $7 \cdot 75^{\mathrm{a}}$ \\
\hline $\mathrm{SE}$ & $0 \cdot 26$ & $0 \cdot 33$ & $0 \cdot 10$ & $0 \cdot 17$ & $0 \cdot 42$ \\
\hline \multicolumn{6}{|l|}{ Recovery of digested purines: } \\
\hline (a) Corrected for endogenous excretion§ & - & - & 0.44 & $0 \cdot 40$ & $0 \cdot 51$ \\
\hline (b) Uncorrected for endogenous excretion & $\cdots$ & - & $1 \cdot 12$ & $1 \cdot 10$ & 0.84 \\
\hline
\end{tabular}

a, b, c Values with different superscript letters were significantly different $(P<0-05)$; SED 0-20.

* For details, see p. 132.

$\dagger$ Calculated as: (purine concentration in ileal digesta $\times$ chromium input $\div \mathrm{Cr}$ concentration in ileal digesta).

$\ddagger$ Calculated as: purine infused - (purine in ileal digesta - mean endogenous purine in digesta).

$\S$ The endogenous excretion was taken as the mean of treatment nos. 1 and 2 , i.e. $3.06 \mathrm{mmol} / \mathrm{d}$.

was 0.913 (SE 0.026) (Table 3). As in Expt 1, the daily excretion of purine derivatives in urine responded rapidly to changes in levels of purine infusion (Table 3 ). The endogenous excretion of the three animals in the present experiment was somewhat higher than in Expt 1 , at 259 (SE 30) $\mu \mathrm{mol} / \mathrm{kg} \mathrm{W}^{0.75}$ per d. This resulted in lower values than in Expt 1 for the 
Table 4. Concentrations of purine derivatives $(\mu \mathrm{mol} / l)$ in the portal and jugular blood of two sheep*

(Values for each animal are means of four daily measurements)

\begin{tabular}{|c|c|c|c|c|c|c|}
\hline & \multicolumn{2}{|c|}{ Allantoin $\dagger$} & \multicolumn{2}{|c|}{ Uric acid $\dagger$} & \multicolumn{2}{|c|}{ Xanthine + hypoxanthine } \\
\hline & Portal & Jugular & Portal & Jugular & Portal & Jugular \\
\hline Sheep A & $142 \cdot 1$ & $140 \cdot 1$ & $8 \cdot 18$ & $7 \cdot 42$ & $24 \cdot 1$ & 14.9 \\
\hline Sheep B & $118 \cdot 1$ & $116 \cdot 1$ & 7.55 & 682 & $23 \cdot 6$ & $14 \cdot 8$ \\
\hline Mean & $130 \cdot 1$ & $128 \cdot 1$ & $7 \cdot 86$ & $7 \cdot 13$ & $23 \cdot 9$ & 14.9 \\
\hline
\end{tabular}

* The two sheep (Blackface, live weight of about $60 \mathrm{~kg}$ ) were given $2 \mathrm{~kg} / \mathrm{d}$ of a pelleted mixed ration containing 0.50 hay, 0.30 rolled barley and 0.10 molasses.

$\dagger$ Difference between the portal and jugular blood was not significant.

\$ Difference between the portal and jugular blood was significant $(P<0.01)$.

(apparent) urinary recovery of infused purines of $0 \cdot 36-0 \cdot 48$ after correction for endogenous excretion (the corresponding values when further corrected for digestibility are shown in Table 3). In agreement with Expt 1, the apparent urinary recovery increased with the level of purine infusion. There was no significant difference in purine derivative excretion between treatments 3 and 4 which had the same purine, but different casein inputs (Table 3).

Expt 3. In the two normally fed sheep, no difference was found between the portal and jugular blood in concentrations of either allantoin or uric acid, although contents of xanthine plus hypoxanthine in the portal blood were significantly $(P<0.01)$ higher (by an average of $60 \%$ ) than in the jugular blood (Table 4).

\section{DISCUSSION}

\section{Daily excretion of purine derivatives}

The results of Expts 1 and 2 show that daily excretion of purine derivatives responded rapidly to changes in supply of exogenous purines. Although there was a carry-over effect from a previous level of purine supply, this was effectively removed within $1 \mathrm{~d}$. It appeared that the digestion of NA, absorption and metabolism of purines and the renal clearance of purine derivatives from the blood were rapid. Further study on the renal clearance of plasma allantoin is reported elsewhere (Chen, 1989).

\section{Digestibility of purines in the Pruteen N14}

Clearly a value derived from only three animals must be viewed with caution. However, the value of 0.913 (SE 0.026) for the true digestibility of Pruteen N14 (Expt 2) was not significantly greater than that of 0.859 (SE 0.022) for microbial NA reported by Storm et al. (1983). Pruteen N14 was clearly highly digestible, and a low digestibility could not have been the explanation for the low recovery of purine derivatives in urine (Expt 1).

\section{Utilization of exogenous purines}

The low recovery of the exogenous purines as their urinary end-products, which ranged from 0.51 to 0.69 for the infused purines or 0.56 to 0.76 for the 'truly' digestible purines (Expt 1), suggests that some of the exogenous purines may have been utilized by the animal. Exogenous purines are absorbed from the intestines as purine nucleosides and free bases (Wilson \& Wilson, 1962). If they are not converted into xanthine, uric acid and allantoin 
on their passage across the intestinal wall, they will be available for incorporation into tissue nucleic acids through the purine salvage pathway (xanthine can be salvaged, but only at a very low rate; Hitchings, 1978). Unlike cattle, sheep intestinal mucosa has only trace xanthine oxidase (EC 1.2.3.2) activity (Al-Khalidi \& Chaglassian, 1965), therefore conversion of exogenous purines into the non-salvageable derivatives should not be quantitatively significant.

This argument is supported by comparison of the concentrations of the purine derivatives in the portal and jugular blood of the two normally fed sheep of Expt 3 (Table 4). No difference was found between the portal and jugular blood in concentrations of either allantoin or uric acid. Concentrations of uric acid and allantoin should have been greater in portal blood if there had been significant degradation of absorbed purines by the intestinal tissues, and therefore it is concluded that in sheep most absorbed purines enter the intestinal tissues and the liver in forms that are available for utilization (salvage). Utilization of exogenous purines by sheep has been documented by Condon et al. (1970), Smith et al. (1974) and Razzaque et al. (1981).

\section{Relationship between excretion of purine derivatives and purine absorption}

Many workers (Antoniewicz et al. 1980; Sibanda et al. 1982; Giesecke et al. 1984; Fijihara et al. 1987) have used a linear model to describe the relationship between purine derivative excretion and purine (or NA) absorption. This assumes the endogenous contribution to the total excretion to be constant (or there to be a constant endogenous: exogenous ratio). Although the results of Expt 1 did demonstrate a strong linear component in the correlation between purine derivative excretion and the exogenous purine input, the fact that the urinary recovery increased consistently with the level of purine infusion further confirms the presence of a non-linear component in the relationship. This should be expected in consideration of a reduced net endogenous contribution to total urinary excretion when exogenous purines are utilized by the animal. This net endogenous contribution can be represented as the amount of purines required to be synthesized de novo to make up the need for replacement of endogenous purine loss. During purine-free nutrition, endogenous purine loss is completely replaced by de novo synthesis. However, when the animal is given an increasing exogenous supply, biosynthesis is gradually replaced by utilization (salvage) of exogenous purines, and becomes completely inhibited with an abundant supply of exogenous purines. This suggestion is supported by the results of Condon et al. (1970), who showed that sheep receiving a normal supply of exogenous purines from the rumen microbes, did not incorporate labelled glycine infused postruminally into their tissue nucleic acids.

If the net endogenous contribution was assumed to be zero, the urinary recovery of truly absorbed $(0 \cdot 913$ of infused) purines became: $1 \cdot 02,0 \cdot 85,0 \cdot 84,0 \cdot 83$ and 0.85 for the five levels of purine infusion respectively (the corresponding values for the infused purines are shown in Table 1). Recovery approached a constant value (average 0.84 ) when absorbed purines exceeded $8.3 \mathrm{mmol} / \mathrm{d}$, which suggests that the maximal inhibition of de novo purine biosynthesis had been achieved. Presumably total replacement of the endogenous loss requires a relatively large exogenous purine input because the exogenous purines entering the liver are partitioned between salvage and degradation.

\section{A model for purine derivative excretion in sheep}

Integration of these concepts enables the quantitative relationship between the excretion of purine derivatives and absorption of exogenous purines to be described. This model is presented diagrammatically in Fig. 2 . It is assumed that the urinary excretion $(Y)$ is a linear function of the plasma pool $\left(Y_{1}\right)$ of purine derivatives,

$$
Y=b Y_{1}
$$




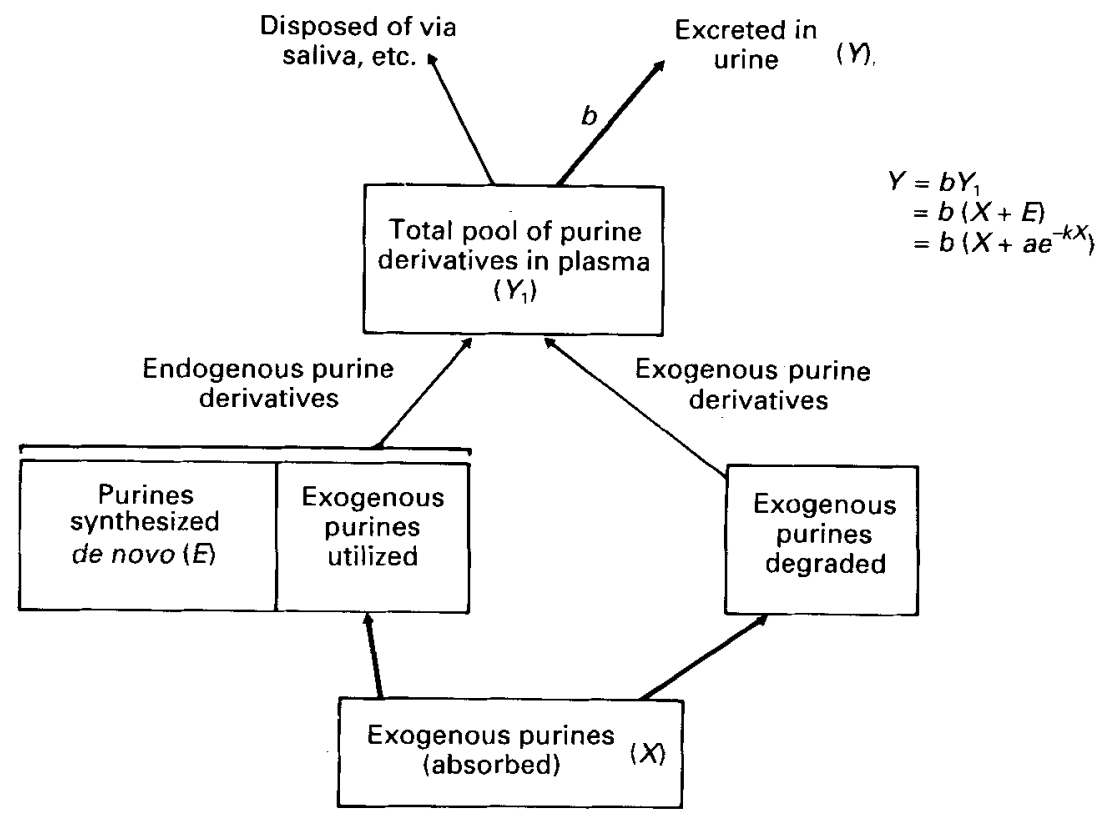

Fig. 2. A model proposed to describe the quantitative relationship between urinary excretion of purine derivatives and the absorption of exogenous purines in sheep.

where the constant $b$ represents the proportion of plasma purine derivatives excreted in urine. The 'plasma pool' is defined as the total amount of purine derivatives of both endogenous and exogenous origins entering the blood and is equal to the sum of the contributions from de novo synthesis $(E)$ and the absorbed exogenous purines $(X) . E$ reduces as $X$ increases and can be empirically defined as:

$$
E=a e^{-k X},
$$

where $a$ is the maximal contribution of de novo purine synthesis (at zero exogenous input). The value $k$ estimates the rate at which the de novo synthesis process is replaced by the exogenous purines. Thus:

$$
\text { urinary excretion } \left.\begin{array}{rl}
(Y) & =b\left(X+a e^{-k X}\right) \\
& =b X+c e^{-k X}
\end{array}\right\}
$$

where $a \times b=c$ which is the endogenous purine derivative excretion (measured at zero input of exogenous purines).

The values from all six animals of Expt 1 were fitted into this model using the maximum likelihood programme (MLP) of Ross (1987) with the following result:

$$
\left.Y=0 \cdot 84 X+2 \cdot 06 e^{-0 \cdot 25 X} \quad \text { (residual } \mathrm{SD}=0 \cdot 600\right),
$$

where $Y$ is urinary excretion of total purine derivatives of both endogenous and exogenous origin (mmol/d); $X$ is absorbed exogenous purine ( $\mathrm{mmol} / \mathrm{d}) ; b$ is $0.84(\mathrm{SE} 0.007)$, and is the proportion of absorbed exogenous purine excreted as derivatives in the urine; $c$ is 2.06 (SE $0 \cdot 201)$, the endogenous derivative excretion $(\mathrm{mmol} / \mathrm{d})$ measured when the animal had no supply of exogenous purine (Table 2) (lambs mean weight 33.6 (SE $1.2 \mathrm{~kg}$ )); $k$ is 0.25 (SF $0.044)$, the rate-constant for the replacement of de novo synthesis of purines by exogenous purines.

When values from each of the six animals were individually fitted into equation 1 , 


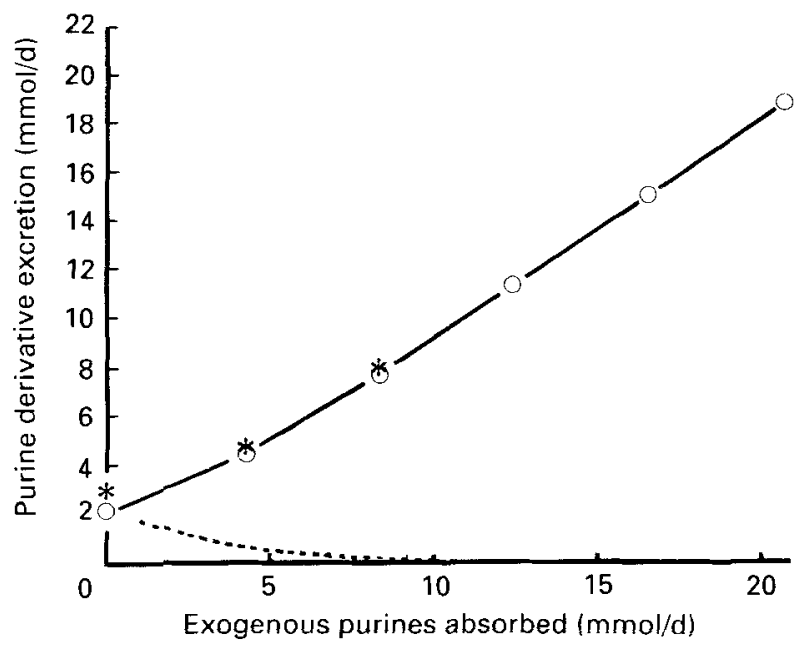

Fig. 3. Urinary excretion of purine derivatives in relation to exogenous purine uptake in six lambs given an abomasal infusion of a microbial nucleic acid concentrate Pruteen N14 (for details, see p. 132). (O-O), Plotted from the equation: $Y=0.84 X+2.06 e^{-0 \cdot 15 x}$, which was derived from the observed values from Expt 1 . The points are means for six lambs, the standard errors being completely masked by the symbols. (-..-), Plotted from $2.06 e^{-0.25 x}$ and represents the net endogenous contribution to the total excretion. ${ }^{*}$ Values from Expt 2, the points being means for three lambs.

parallel curve analysis using MLP showed no significant differences in the derived parameters $(b, c$ and $k$ ) between the six individual curves. The observed values for daily excretion of purine derivatives in Expt 1 and the fitted values calculated from the common curve (equation 2) are plotted against absorbed purines as shown in Fig. 3. Values from Expt 2 were then plotted and fitted well.

When expressed on a metabolic body-weight basis, the value for $c$ became $0 \cdot 150$ $\mathrm{mmol} / \mathrm{kg} \mathrm{W}^{0.75}$ per $\mathrm{d}$. This is close to the mean of 0.168 (SE 0.005 ) observed in twenty-nine sheep (Chen et al. 1990). The relationship then becomes

$$
Y=0 \cdot 84 X+0 \cdot 150 \mathrm{~W}^{0.75} e^{-0 \cdot 25 x} .
$$

The constant $b$ of 0.84 implies that 0.16 of the plasma purine derivatives were lost through channels other than renal excretion. It has been shown that some purine derivatives can be irreversibly lost via salivary flow into the rumen (Chen, 1989; Chen et al. 1989). There is also evidence for loss as a direct secretion of purine derivatives into the gut (Altman \& Dittmer, 1961). Although the loss from animals of the present work was relatively constant at $\mathbf{0 \cdot 1 6}$, it is not certain that this value will apply to all conditions of feeding.

\section{Difference between the endogenous and exogenous purine derivatives}

The result as shown in Fig. 1 demonstrate that as the contribution of purine derivatives of exogenous origin was increased, so also did the proportion of derivatives excreted as allantoin. A possible explanation is that the derivatives are produced at different sites in the body which have different enzyme profiles. Endogenous purine derivatives are produced in all tissues. In sheep all extrahepatic cells contain only trace activities of xanthine oxidase (Al-Khalidi \& Chaglassian, 1965), with the effect that a higher proportion of endogenous purine derivatives passing into and being transported by the blood are as xanthine, hypoxanthine and uric acid (sheep blood contains no xanthine oxidase and only trace levels of uricase (EC 1.7.3.3); Chen et al. 1990). However, purine derivatives originating from 
the degradation of exogenous purines are produced mainly in the liver, which contains high activities of both xanthine oxidase and uricase. A greater proportion of the purine derivatives would, therefore, be in the form of allantoin. Thus the final composition of purine derivatives in plasma, and subsequently in the urine, will depend directly on the relative contributions from the endogenous and exogenous sources.

\section{Estimation of purine absorption from purine derivative excretion in sheep}

Since the proportion of allantoin in total purine derivative excretion is affected by the amount of purine absorbed, the sum of all purine derivatives, rather than of allantoin alone, should be used as the estimator. This will be particularly important at low levels of feed intake by the host animal which give rise to low levels of microbial biomass production and hence of exogenous purine supply.

The use of purine derivative excretion to estimate the amount of microbial purines absorbed will require a correction for the endogenous contribution to the total purine derivative excretion when input of absorbed microbial purines is low. This will apply when the total urinary excretion is less than about $0.6 \mathrm{mmol} / \mathrm{kg} \mathrm{W}^{0.75}$ per $\mathrm{d}$. If the urinary excretion is measured as $d \mathrm{mmol} / \mathrm{d}$ (i.e. when $Y=d$ ), an estimate of the purines absorbed $(X ; \mathrm{mmol} / \mathrm{d})$ can be obtained by finding the root for the function:

$$
f(X)=0 \cdot 84 X+0 \cdot 150 \mathrm{~W}^{0.75} e^{-0.25 X}-d,
$$

(where $\mathrm{W}^{0.75}$ is the metabolic body-weight in $\mathrm{kg}$ ), when $f(X)=0$. The best approximate value for the root can be acquired by means of the Newton-Raphson iteration process using the formula:

$$
X_{(n+1)}=X_{n}-f\left(X_{n}\right) \div f^{\prime}\left(X_{n}\right),
$$

where

$$
f^{\prime}(X)=0.84 X-0 \cdot 038 \mathrm{~W}^{(1 \cdot 75} e^{-0 \cdot 25 x} \text {. }
$$

Thus, given an initial value of $X_{1}=d \div 0.84, X_{2}, X_{3} \ldots$ and $X_{n+1}$ can be subsequently calculated, and as the iteration process proceeds, $X_{(n+1)}$ approaches the root $(r)$ that follows:

$$
Y=0 \cdot 84 r+0 \cdot 150 W^{0.75} e^{-0 \cdot 25 r}=d .
$$

If the total urinary excretion is greater than about $0.6 \mathrm{mmol} / \mathrm{kg} \mathrm{W}^{0.75}$ per $\mathrm{d}$, the endogenous contribution will be very small, and may be taken as zero. Generally this will be applicable to normally fed sheep nourished above about 0.8 times their maintenance energy requirement when the amount of purines absorbed can simply be calculated as:

$$
X=d \div 0 \cdot 84 \text {. }
$$

The work reported here has defined in sheep the quantitative relationship between urinary excretion of purine derivatives and absorption of exogenous purines. The factor of 0.84 which adjusts for the loss of purine derivative by routes other than excretion in the urine is our best estimate. Whether this factor is applicable to all situations has yet to be determined.

The authors thank Mr D. J. Kyle for his skilful care of the animals on intragastric infusion, Dr G. E. Lobley for his helpful criticism of the manuscript and Dr M. Franklin for his advice on the statistical analysis. 


\section{REFERENCES}

Agricultural Research Council (1984). The Nutrient Requirements of Ruminant Livestock, Suppl. no. 1. Slough: Commonwealth Agricultural Bureaux.

Al-Khalidi, U. A. S. \& Chaglassian, T. H. (1965). The species distribution of xanthine oxidase. Biochemical Journal 97, 318-320.

Altman, P. L. \& Dittmer, D. S. [editors] (1961). Blood and Other Body Fluids, pp. 400-414. Washington, DC: Federation of American Societies for Experimental Biology.

Antoniewicz, A. M., Heinemann, W. W. \& Hanks, E. M. (1980). The effect of changes in the intestinal flow of nucleic acids on allantoin excretion in the urine of sheep. Journal of Agricultural Science, Cambridge 95, 395-400.

Chen, X. B. (1989). Excretion of purine derivatives by sheep and cattle and its use for the estimation of absorbed microbial protein. PhD Thesis, University of Aberdeen.

Chen, X. B., Kyle, D. J., Whyte, C. C., Hovell, F. D. DeB. \& Ørskov, E. R. (1989). Uric acid and allantoin in plasma and saliva of sheep. Proceedings of the Nutrition Society 48, 88A.

Chen, X. B., Ørskov, E. R. \& Hovell, F. D. DeB. (1990). Excretion of purine derivatives by ruminants: endogenous excretion, differences between cattle and sheep. British Journal of Nutrition 63, 121-129.

Condon, R. J., Hall, G. \& Hatfield, E. E. (1970). Metabolism of abomasally infused ${ }^{14}$ C-labelled RNA adenine, uracil and glycine. Journal of Animal Science 31, 1037-1038 (abstr).

Fujihara, T., Ørskov, E. R. \& Reeds, P. J. (1987). The effect of protein infusion on urinary excretion of purine derivatives in ruminants nourished by intragastric nutrition. Journal of Agricultural Science, Cambridge 109 , $7-12$.

Giesecke, D., Stangassinger, M. \& Tiemeyer, W. (1984). Nucleic acid digestion and urinary purine metabolites in sheep nourished by intragastric infusions. Canadian Journal of Animal Science 64, Suppl. 144-145.

Hitchings, G. H. (1978). Uric acid: chemistry and synthesis. In Uric Acid, pp. 1-20 [W. N. Kelly and J. M. Weiner, editors]. Berlin, Heidelberg and New York: Springer-Verlag.

Hovell, F. D. DeB., Ørskov, E. R., Kyle, D. J. \& MacLeod, N. A. (1987). Undernutrition in sheep. Nitrogen repletion by $\mathrm{N}$-depleted sheep. British Journal of Nutrition $\mathbf{5 7}, 77-88$.

Lawes Agricultural Trust (1983). Genstat 4 User Manual. Rothamsted: Rothamsted Experimental Station.

Lindberg, J. E. (1985). Urinary allantoin excretion and digestible organic matter intake in dairy goats. Swedish Journal of Agricultural Research 15, 31-37.

McAllan, A. B. \& Smith, R. H. (1973). Degradation of nucleic acid derivatives by rumen bacteria in vitro. British Journal of Nutrition 29, 467-474.

Orskov, E. R., Grubb, D. A., Wenham, G. \& Corrigall, W. (1979). The sustenance of growing and fattening ruminants by intragastric infusion of volatile fatty acids and protein. British Journal of Nutrition 41, 553-558.

Pentz, E. I. (1969). Adaptation of the Rimini-Schryver reaction for the measurement of allantoin in urine to the autoanalyzer: allantoin and taurine excretion following neutral irradiation. Analytical Biochemistry $27,333-342$.

Razzaque, M. A., Topps, J. H., Kay, R. N. B. \& Brockway, J. M. (1981). Metabolism of the nucleic acids of rumen bacteria by pre-ruminant and ruminant lambs. British Journal of Nutrition 45, 517-527.

Ross, G. J. S. (1987). MLP User Manual. Rothamsted: Rothamsted Experimental Station.

Sibanda, S., Topps, J. H., Storm, E. \& Ørskov, E. R. (1982). The excretion of allantoin by ruminants in relation to protein entering the abomasum. Proceedings of the Nutrition Society 41, $75 \mathrm{~A}$.

Smith, R. C., Moussa, N. M. \& Hawkins, G. E. (1974). Utilization of the nucleic acids of Escherichia coli and rumen bacteria by sheep. Journal of Biological Chemistry 32, 529-537.

Stevenson, A. F. \& deLangen, H. (1960). Measurement of feed intake by grazing cattle and sheep. VIII. Modified liver digestion method for determination of chromic oxide in faeces. New Zealand Journal of Agricultural Research 3, 314-319.

Storm, E., Brown, D. S. \& Ørskov, E. R. (1983). The nutritive value of rumen micro-organisms in ruminants. 3. The digestion of microbial amino and nucleic acids in, and losses of endogenous nitrogen from, the small intestine of sheep. British Journal of Nutrition 50, 479-485.

Storm, E. \& Orskov, E. R. (1983). The nutritive value of rumen microorganisms in ruminants. 1. Large-scale isolation and chemical composition of rumen micro-organisms. British Journal of Nutrition 50, 463-470.

Technicon Instruments Co. (1979). Uric acid Technicon Method no. SD4-0013FM9. Tarrytown, NY: Technicon Instruments Co.

Uden, P., Colucci, P. E. \& Van Soest, P. J. (1980). Investigation of chromium, cerium and cobalt as markers of digesta. Rate of passage studies. Journal of the Science of Food and Agriculture 31, 625 632.

Wilson, D. W. \& Wilson, H. C. (1962). Studies in vitro of the digestion and absorption of purine ribonucleotides by the intestine. Journal of Biological Chemistry 237, 1643-1647. 